\title{
DEEPENING INDO-JAPAN RELATIONS AND IT'S IMPACT ON SOUTH ASIA
}

\begin{abstract}
Sudhir Singh
In the post - Cold War era, Japan and India - are increasingly playing a crucial role in shaping the world order of the 21st century. Hence a deepening of Indo-Japanese relationship is mutually beneficial for both countries in Asia in particular, and at the global level in general. Since both countries are important stakeholders of the Asian balance of power, therefore their increasing bonhomie will ensure multi-polarity within a new emerging Asian security architecture. Such a close relationship will counter the rise of China, mitigate the ever present threat of Pakistan and keep in check the existing tensions between the United States and China. The article examines Indo-Japan relations via the Act East policy as well as within the context of an Asian geopolitical political uncertainty. Overall, the article concludes that closer Indo Japan relations not only benefits both sides economically, politically but equally ensures that the stability of Asia is well preserved.
\end{abstract}

Keywords: India, Japan, China, multi-polarity, Act East policy

\section{Introduction}

The post-Cold War scenario has witnessed a tectonic shift in international politics, where the Asian continent has emerged as the main theatre of global politics. Certainly, as two Asian economies and military powers -Japan and India - are increasingly playing a crucial role in shaping the world order in the 21 st century. In fact, since the beginning of the current century, India and Japan have taken a plethora of initiatives to transform their bilateral ties. For instance, bilateral trade between the two countries reached $\$ 18.51$ billion in 2012-13. In recent years, there has been a sharp rise in the flow of Japanese foreign direct investments into India. Japanese companies dealing in the information technology sector have also shown their eagerness to invest in there. Moreover, Japan has heightened its commitment to infrastructure development in India. Japan's Official Development Agency (ODA) has already left its footprint in the Delhi Metro project. The Delhi-Mumbai Industrial Corridor (DMIC) project, with the Dedicated Freight Corridor (DFC) as its core backbone, serves as an important symbol of advanced bilateral collaboration in Indian infrastructural development. The DFC project is already undergoing construction.

Both New Delhi and Tokyo have convergences of culture, history, political system. For instance, ever since Buddhism was introduced in Japan in the late sixth century, it has played a very important role in connecting the two countries. Both countries have faith in the freedom of speech and rule of law. In addition, Japan and India are the only countries to maintain a parliamentary system of democracy in Asia for more than seven decades in the post-war period. Although Japan-India bilateral relations have been cordial, but it has yet to achieve its full potentialities. At the same time, however, Japan-India relations have largely been free from any historical baggage. In fact, the Japanese appreciate India for extending its warm friendship to them in the aftermath of the World War II. The Japanese Emperor Akihito's and Empress Michiko's visit to India in late 2013, followed by the participation of Prime Minister Shinzo Abe as the chief-guest at the Republic Day celebration in New Delhi on 26 January 2014 underscored the growing bonhomie between India and Japan. In the backdrop of a looming North Korea threat, Prime Minister (PM) Abe called for a snap poll in October 2017 and got re-elected. It is unprecedented in post-war scenario given the fragile nature of Japanese politics. 
The sustainability of PM Abe's government has emboldened Tokyo's position as an important Asian power in the backdrop of a rising China. In addition, it has further accelerated IndoJapan relations. PM Abe is dedicated in upgrading the Indo-Japan relations and firmly believes that it will provide a justice based international system in Asia and preserve a multi-polarity framework in the region.

Japan and India have highly complementary economies that have yet to be fully exploited. Japan has ample capital and is highly advanced in technological skills and product development, whereas India is endowed with a huge market and abundant human resources. Japan has outstanding manufacturing abilities, whereas India has advantages in information technology (IT) services and bio-informatics. Given its huge domestic market, abundant talented human resources, and promise as a destination for production and export bases, India is becoming more important for Japan. Correspondingly, Japan is expected to play an indispensable role in upgrading Indian manufacturing skills and infrastructure development. Japan is also expected to be a potential market for India's IT exports.

It is investment rather than trade where Indo-Japan economic relations have experienced a more dynamic trend. Japan ranked fourth, accounting for eight percent of the total accumulated volume of foreign direct investment (FDI) inflows into India from April 2000 to March 2014. Since 2007, Japanese FDI into India began to show sustainable expansion. Japanese FDI in India increased from US\$ 1,562 million in 2010-11 to US \$2,972 million in 2011-12, but declined slightly to US\$ 1,718 in 2013-14, ranking fourth after Mauritius, Singapore and UK. The arrival of Prime Minister Narendra Modi led National Democratic Alliance (NDA) government in New Delhi in May 2014 has further expanded bonhomie with Japan. Modi led Bharatiya Janata Party (BJP) won the 2014 Lok Sabha elections by a clear majority. Since then, Prime Minister Modi and Prime Minister Shinzo Abe have an excellent chemistry, which is evident from the fact that in the last three years there have been intense engagements at the highest political level with ten bilateral meetings between the two leaders. As a result, Prime Minister Shinzo Abe has pledged to invest \$ 35 billion in India by 2019.

As the end of the Cold War has seen the emergence of many powerful countries, there is a debate if the world is on the verge of being transformed from being unipolar led by the US to a multi-polar entity led by many power countries / blocks. While most Asian powers share the view that efforts must be made to facilitate the emergence of a multi-polar global order, China, unlike Japan, India and other important Asian countries, wishes to establish its hegemony in Asia by forcing others to accept its dominance. This is one of the reasons for India and Japan to work together to prevent China from realising its ambition. More to the point, shared geo-political, economic and strategic interests is expected to continue to shape future bilateral relationship.

No concept in the realm of international politics has been discussed more often than the balance of power. It has been defined in so many ways, despite diversity of description, it has remain an ambiguous idea. Used objectivity or descriptively, the term indicates the relative distribution of power among states into equal or unequal shares. Traditionally, it refers to a state of affairs in which no one state dominates over others. Prescriptively, it refers to a policy of promoting power equilibrium on the assumption that unbalanced power is dangerous. Prudent states that are at a disadvantage in the balance of power will (or at least should) form an alliance against a potentially hegemonic state or take other measures to enhance their ability to restrain a possible aggressor. Also, one state may opt for a self-conscious balancing role, changing sides as necessary to preserve equilibrium. A balance of power policy requires that a state moderates its independent quest for power, since too much power to one state may bring 
out self-defeating reactions of fear and hostility from other states. ${ }^{1}$ As China, Japan, India and Vietnam are indulging in the balance of power game within Asia and other countries do not want China's supremacy, there is deepening bonhomie between India and Japan since last two decades. In recent years, China has shown that it would use force to take islands under Japanese rule. In many parts of China including Hong Kong, protests against Japan had been organized, demanding the re-capture of Japan administered islands in the East China Sea. Countries like United States and India have also insisted amicable resolution to such disputes and adherence to international laws by all concerned parties. Because of border disputes, India is also apprehensive about Chinese reactions therefore it has strengthened its bilateral relationship with Japan significantly. The prevailing trust deficit between India and China is in contrast with the moorings of globalization, as it claims that good trade between two adverse countries has the capacity to reduce tension. Despite high voltage trade between India and China, bilateral relations are still thorny and core border issues remain unresolved. In contrast, despite the low volume of trade, Japan and India have a strong friendship which is bound to deepen given the prevailing security architecture of Asia. These recent consideration indicate that the balance of power theory is working well in Asia and is sustainable due to Chinese reluctance to accommodate the aspirations of other countries. In 2016, by rejecting the international arbitration which was in favour of the Philippines in South China Sea dispute, China has shown clearly an attitude that disrespects international laws.

However, the theory of balance of power according to its proponents has come into being with the theory of Prisoner's Dilemma. The balance of power is a kind of compromise among states that find its order preferable to absolute chaos, even though it is a system that favours the stronger and more prosperous states at the expenses of weaker ones. Great powers play the dominant role in balance of power system because of their preponderant military force and their control of key technologies. ${ }^{2}$ The Cold War era just after the end of the second World War is a classic example of balance of power between the United States and the Soviet Union. In the post - Cold War era, the prevalence of an anarchic international environment has created fear where military build-ups and rivalry among powers has left every harbinger of the international system insecure, therefore all countries are trapped in a dilemma. This kind of phenomenon is called the Security Dilemma. ${ }^{3}$

Many political pundits including Keshore Mahbubni and others have suggested that the 21 st century will be an Asian century. But, the billion dollar question is why Asian powers are not cooperating and thus negating the utopian idea of cooperation among Asian countries is better than among European countries. China, India, Japan, South Korea, Indonesia, Iran and Vietnam are some of the important Asian powers. The changing power configuration in Asia has negated Nehru's hypothesis of Asian consolidation and more often than not, Asia seems to follow the European model of conflict. However, interestingly, in the post Second World era, Europe has emerged as a beacon of cooperation which should be emulated by other regional groupings. Reality is that major Asian countries are not cooperating because there is a divergence of interests among them. China wants its unipolar dominance over Asia but at the same time prefers multi-polarity at the global level. India, Japan, South Korea, Indonesia, Iran and Vietnam prefer a more globe multilateral arrangement.

Long back, Kautilaya, one of the earliest strategic Indian thinkers, had stated that convergences of interests is the basic determinants of foreign policy. There are deepening convergences of interests between India and Japan. It is an open secret that bilateral relations were average during the Cold War. Even after the Cold War during the 1998 Pokhran bomb

\footnotetext{
${ }^{1}$ Martin Grifiths and Terry O Callaghan, Key Concepts in International Relations, Routledge, London, 2004, p 2.

${ }^{2}$ Ibid, p 13.

${ }^{3}$ John H. Herz, "Idealist Internationalism and Security Dilemma," World Politics, Vol. 2, 1950, pp 157-158.
} 
blast, many countries including Japan reacted sharply. The incident suspended all political exchanges and even economic assistance was frozen by Japan for nearly three years. However, a turnaround in the damaged ties was achieved in August 2000, when the then Japanese Prime Minister Yoshiro Mori paid a five-day visit to India. Mori and then the Indian Prime Minister Atal Bihari Vajpayee called for a "global partnership." From then on, relations have percolated in a sustainable manner. During the visit of the Indian Prime Minister Manmohan Singh to Tokyo in 2006, the two Prime Ministers decided to promote a "strategic partnership" instead.

One factor that contributed to this change is the China-Japan friction that existed for many years. India too has problems with China. In July 2012, Japan recalled its envoy from Beijing over the disputed territory in the East China Sea. ${ }^{4}$ Simultaneously, another coincidence took place in the same month, when, China refused to issue a visa to an athlete belonging to Arunachal Pradesh, which China perceives as its own territory. ${ }^{5}$ Despite 20 rounds of high level bilateral dialogues, there has been no progress over the thorny boundary dispute. In addition, China also blocked the Indian move to declare Jaish-E-Mohhmad chief, Maulana Massod Azhar, as global terrorist by the United Nations within the backdrop of Pathankot attack in January 2016.

Other factors also exists. Japan and India's dreams are also converging in the post-Cold War Asian scenario. Both have realized that cooperating together will not only safeguard their interests, but also able to establish a multi-polarity within Asia. Interestingly, other important countries excluding China are also thinking along the same line. These prevailing convergences have brought India and Japan closer. Chinese officials are worried that the growing relationship between India and Japan, its two main rivals in Asia, is meant to contain and counter Beijing. According to two leading foreign policy experts from the China Institute of International Studies "India's border disputes with China have yet to be resolved, therefore it views a stronger relationship with Japan as a way to counter balance China's growing influence in the Asia-Pacific region." As China's dispute with Japan escalates over islands in East China Sea, China seems worried that India will throw its weight in favour of Tokyo. Chinese experts believe that India and Japan share a strategic common ground in regards to China. For the first time probably in recent history, Chinese experts have accepted that India is working similar to the reciprocation of Chinese policy of encircling India within South Asia and therefore deepening its relationships with all estranged neighbours of China. ${ }^{7}$ In the backdrop of the South China Sea dispute, the Chinese reaction to the international judgement in regards to the Philippines has made ASEAN claimants vary of Beijing.

India-Japan relations have undergone a significant and qualitative shift in recent years. It is a fact that after the end of the Cold War, India has emerged as a stable economic hub and Japan being one of the biggest global investors is at aware of the increasing profile of India at the global stage. When Japanese Prime Minister, Mr. Yoshihiko Noda, came to India on a State visit on 27-28 December, 2011, for the Annual Bilateral Summit, a Joint Statement titled 'Vision for the Enhancement of India-Japan Strategic and Global Partnership upon entering the year of the 60th Anniversary of the Establishment of Diplomatic Relations' was signed. The Japanese side renewed its commitment to be involved in flagship infrastructure projects like the Delhi-Mumbai Industrial Corridor Project and the Dedicated Freight Corridor West Project, and expressed support for the new Chennai- Bangalore Industrial Corridor Project. Such close economic cooperation further strengthened bilateral relations.

\footnotetext{
4 "Japan Recalls China envoy over territory dispute", The Hindu, New Delhi, July 16, 2012.

${ }^{5}$ Saibal Dasgupta, "MEA fumes as sports min team ignores China sunb," The Times of India, New Delhi, July $15,2012$.

${ }^{6}$ Saibal Dasgupta, "China sees growing India-Japan ties as move to counter it," The Times of India, New Delhi, September 20, 2012.

${ }^{7}$ Ibid.
} 


\section{Indo-Japan Deepening Relations in the Context of 'Act East' Policy}

Two decades on, engagement with the Asia-Pacific has become an integral component of Indian foreign policy with bipartisan support. In 2003, the geographical focus and agenda of the policy was expanded significantly to include Australia and East Asia, as well as broader economic and security issues. ${ }^{8}$ 'Look East' policy has thus developed into a multi-pronged strategy involving many institutional mechanisms at multilateral and bilateral levels, economic links, and defence engagement. ${ }^{9}$ India's trade with North and Southeast Asia now represents about a quarter of its global trade; outweighing that with the United States and the European Union. ${ }^{10}$ China has become India's top trading partner, with bilateral trade growing from roughly \$US 7 billion in 2003-2004, to \$US 65 billion in 2013-2014. ${ }^{11}$ In the same period, twoway trade with ASEAN member states has grown from approximately \$US 13 billion to \$US 74 billion, making its trade with the region as a whole even more significant than with China. ${ }^{12}$

India's engagement with East and Southeast Asia has also developed strategic dimensions. In particular, as China's relationship with India's neighbours in the Indian Ocean deepen, the strategic relevance of India's own connections with neighbouring Asian states in the Pacific Ocean will likewise grow. Importantly, China's assertiveness, particularly in maritime territorial disputes in the East and South China Sea, is prompting Asia-Pacific nations to look to India to play a balancing role; demonstrated by the accelerated outreach to India by states such as Japan and Vietnam. With almost 55 per cent of India's trade traversing through the Malacca Straits, India does not want to see these crucial waterways dominated by a strategic competitor. ${ }^{13}$ Since coming to power in 2014, the government of Prime Minister Narendra Modi has lent India's 'Look East' policy even greater momentum, unveiling an upgraded 'Act East' policy during the India- ASEAN Summit in Myanmar in November 2014. This is far -far then just a rebranding. The message is that India is becoming increasingly willing to play a more active and prominent strategic role, exemplified by enhanced defence diplomacy in East and Southeast Asia. As the most advanced Asian naval power, and as a potential source of considerable investment and technological assistance, Japan offers significant partnership opportunities as India deepens relations with East Asia. For the moment at least, Japan and India are still relatively minor economic partners, with a bilateral trade volume of only \$US16 billion in 2013-14, and almost \$US2 billion in investment in 2013. ${ }^{14}$

However, it is the strategic potential of the relationship that is most significant. Again, China's assertiveness in the East China Sea and along the Ladakh border has created an additional impetus for closer Indo-Japan ties. The Doklam standoff (June-August 2017) has further vindicated China's offensive realism. The lack of historical baggage and mutual recognition of each other's importance in Asia's rapidly changing geopolitical situation has, in recent years, induced India to priorities relations with Japan. Soft power synergy between both countries has further facilitated the process. Under the UPA-2 government led by Manmohan

\footnotetext{
${ }^{8}$ Yashwant Sinha, "Speech by External Affairs Minister Shri Yashwant Sinha at Harvard University," (speech, Harvard University, Cambridge, 29 September 2003) available at http://mea.gov.in/SpeechesStatements.htm?dtl/4744/Speech+by+External+Affairs+Minister+Shri+Yashwant + Sinha+at+Harvard+University.

${ }^{9}$ G. V. C. Naidu, "India and East Asia: The Look East Policy," Perceptions 18, no.1, 2013, p 73.

${ }^{10}$ Figures available from: "Trade Statistics," business.gov.in, http://business.gov.in/trade/trade_stat.php.

${ }^{11}$ Figures available from: "Trade Statistics," business.gov.in, http://business.gov.in/trade/trade_stat.php.

${ }^{12}$ Figures available from: "Trade Statistics," business.gov.in, http://business.gov.in/trade/trade_stat.php.

${ }^{13}$ David Scott, "India's Role in the South China Sea: Geopolitics and Geo-economics in Play," India Review, Vol. 12, no.2, 2013, p 55.

${ }^{14} \mathrm{Ibid}, \mathrm{p} 55$.
} 
Singh, PM Shinzo Abe was the Chief Guest at India's Republic Day Parade in January 2014. ${ }^{15}$ He has long been a proponent of closer India-Japan ties, arguing for the creation of a Japanand India-led 'broader Asia' partnership during his previous term as Prime Minister. ${ }^{16}$ PM Abe sustainable electoral victory since last three terms including October 2017 snap polls has further accelerated this process. During the Doklam standoff (2017), Japan extended its support to India. However, the test of this partnership will be the extent to which India and Japan can commit to assisting each other in the event of a crisis.

Under PM Modi, India's relationship with Japan will acquire additional impetus brought about by his close personal relationship with Abe. Their affinity has already borne results with the inauguration of a new Special Strategic and Global Partnership during Modi's September 2014 visit to Japan, his first outside of India's immediate neighbourhood. The partnership arises from the two countries' "convergent global interests, critical maritime interconnection and growing international responsibilities" and Japan's place "at the heart of India's 'Look East' policy." 17 However, the inability to conclude a civil-nuclear deal during Modi's 2014 visit to Japan demonstrated that progress in the relationship will not be driven solely by the political will of the two leaders. On top of a commitment to invest around \$US 35 billion in Indian infrastructure projects over the next five years, Modi's trip brought about agreements to enhance military ties between India and Japan. ${ }^{18}$ The two leaders signed a Memorandum of Cooperation and Exchanges in the Field of Defence, and noted the importance of regular bilateral maritime exercises and Japan's participation in the Malabar naval exercise with India and the United States. ${ }^{19}$ Further, PM Shinzo Abe made another visit to India in December 2015, showcasing India's importance to Japan in particular and countries of AsiaPacific in general. PM Abe again visited Ahmedabad in September 2017 and both countries inked many deals including the Ahmedabad-Mumbai High Speed Rail Corridor. Maritime security remains a natural avenue for partnership for the two Indo-Pacific powers, adding the potential to cooperate with other regional navies such as Australia. ${ }^{20}$ The liberalization of Japan's defence export rules will additionally allow Japanese defence firms to fill a gap in India's huge weapons market, likely beginning with the Shin Maywa US-2 amphibious seaplane. ${ }^{21}$ Further, PM recent visit to Japan in November 2016 for the annual bilateral strategic submit equally produced many important deals including the much awaited civilnuclear deal. It is expected that such high level visits will further propel the momentum of bilateral and initiate lucrative dividends in the near future.

\footnotetext{
15 Danielle Rajendram, "India-Japan Ties in the Face of a Rising China," China India Brief \#20, Lee Kuan Yew School of Public Policy, 28 January 2014, available at http://kyspp.nus.edu.sg/cag/publication/china-indiabrief/china-india-brief-. 20

16 "Shinzo Abe, "Confluence of the Two Seas," (speech, Parliament of the Republic of India, 22 August 2007).

${ }^{17}$ Government of India, Ministry of External Affairs, "Tokyo Declaration for India-Japan Special Strategic and Global Partnership," 1 September 2014, available at

http://www.mea.gov.in/bilateraldocuments.htm?dtl/23965/Tokyo+Declaration+for+India++Japan+Special+Strat e gic +and+Global+Partnership.

18 "The Latest Special Relationship in Asia," Financial Times, 3 September 2014, available at http://www.ft.com/intl/cms/s/0/d7558ebc-337d-11e4-

85f100144feabdc0.html? siteedition=intl\#axzz3CK4OHP4Y.

19 Tokyo Declaration, September 2014.

${ }^{20}$ Rory Medcalf and C. Raja Mohan, "Responding to Rivalry: Australia, India and Middle-Power Coalitions,", Lowy Institute, (Sydney: Lowy Institute for International Policy, 2014).

${ }^{21}$ Sudhi Ranjan Sen, "For First Time Since World War 2, Japan will Sell Military Equipment. To India," NDTV, 2 September 2014, available at http://www.ndtv.com/article/india/for-first-time-since-world-war-2-japan-willsellmilitary- equipment-to-india-585231.
} 


\section{Deepening Bonhomie in the Backdrop of an Indo-Pacific Debate}

The shared vision for peace and stability between India and Japan has been due to the recognition of the Indo-Pacific as a region indispensable to each nation's national security. It is an area which stretches from Indian Ocean to Pacific. It is a newly coined term where India, United States, Japan and Australia have vowed to ensure peace and stability. However, its nomenclature has been painful for China. China is trying to disturb the maritime order in the Indo-Pacific through its dominance and negation of relevant international laws in the South China Sea. In contrast, India, Japan and the United States are set to defend multi-polarity in Indo-Pacific. ASEAN countries are also with India and Japan to keep this important area peaceful for promotion of their prevailing prosperity and security. In the backdrop of a rising China, Indo-Pacific debate has been a pulling factor for both India and Japan. Durable peace in the region serves the national interests and global peace agenda of both countries.

\section{The United States as a Factor}

President George W. Bush of the United States who ruled for 8 years from 2001 to 2009, understood India's importance. He had intended to provide an enhanced status for the country in Asia. However, the foundation was already laid in the last days of President Clinton's tenure, when Indian prime minister, Atal Bihari Vajpayee defined that United States and India are natural allies in 2000. During President Bush era, this relationship was further expanded, which put China in a situation known as 'Prisoner's Dilemma' in international politics. China was of course one of the factors that allowed President Bush to reach out to India. This was commonly articulated by Robert Blackwill, the American Ambassador to India for first two years of the Bush Administration.

President Bush based his transformation of United States-India relations on the core strategic principle of democratic India as a key factor in balancing the rise of Chinese power. To be clear, this was in contrast to the concept of containing China. Rather, it is centred on the idea that the United States and India in the decades ahead both had enormous equities in promoting responsible international policies in regards to China and that deep bilateral cooperation was vital to the national interests of both countries. It was with this strategic paradigm in mind that the Bush Administration treated India with at least as much importance as China. ${ }^{22}$

China continuously looms large in India's foreign policy considerations. The baggage of 1962 still hounds the Indian psyche. Meanwhile, India-United States bonhomie remained a sustainable affair for more than one and a half decade. China is very sensitive to a growing USIndia relationship. China is fearful that this ongoing closeness is bound to weaken her position and will end up in establishing a new balance of power in Asia which will be based on multipolarity.

At the same time, at a higher international level of analysis, the Sino-Pakistani axis needs to be situated in the rivalry between China and Japan, India, and the United States. Since Kargil till 2013, China took a neutral position regarding India-Pakistan relations. With the deepening of India's bonhomie with the United States and Japan in recent years, China has become apprehensive that these three nations intend to contain it. Therefore, it has enhanced Pakistan's traditional role as China's balancer against India. Beijing is too concerned that India will move into alignment with Japan as Tokyo throws off its post-1945 military limitations under Article 9 of the Japanese constitution. A steadily intensifying maritime rivalry is already

22 “Transcript: Senior Ex-Diplomat on India-United States Relations", Financial Times Online, 6 May 2009 , available at http://www.ft.com/cms/s/0/1ec735fe-3a12-11de-8a2d-00144feabdc0.html. 
underway between China, on the one hand, and Japan, India, and the United States, on the other hand, over control of sea lanes of communication (SLOC) between the Bal el-Mandeb and the Hormuz Strait in the west and the Malacca Strait in the east. ${ }^{23}$ A chronic Chinese fear is that India will join the United States, Japan, and Australia to "pin" the Chinese navy into the western Pacific and out of the Indian Ocean, rendering vulnerable China's SLOCs. Chinese apprehensions became acute when Shinzo Abe re-election as the prime minister in 2012, 2014 and in 2017. In this context, "friendship" diplomacy toward New Delhi is a key Chinese strategy to counter India's drift towards participation in the Japan-U.S. "anti-China coalition" being peddled (or so Chinese analysts believe) by Washington and Tokyo. In many ways, China's irresponsible behaviour in the United Nation to block Azhar as an international terrorist and open opposition of India for Nuclear Suppliers Group (NSG) club membership vindicates Chinese attitude. In May 2016, India, United States and Japan had a joint Malabar Naval exercise in the troubled waters of South China Sea. Although these exercises are routine naval activities but it frightened China. Moreover, despite huge economic assets, China is vulnerable as it does not have friends around its borderlands.

So it is not surprising that China-Pakistan relations have strengthened over the years. China inked a deal with Pakistan to develop the Gwadar port in 2013. China declared its ambitious China-Pakistan Economic Corridor (CPEC) under President Xi's 'One Belt One Road' ambitious connectivity plan, which will connect Gwador to Kashgar, to the western Chinese turbulent town of Xingjiang. The Gwadar port, which will be developed and operated by Chinese companies, will have both economic and strategic advantages for Beijing. It will enable China to re-route oil and gas from the Gulf through pipelines that would bypass the West-dominated Malacca Straits, thus providing China with one more alternative route, besides the Sittwe-Kunming pipeline in Myanmar. Again, control over Gwadar would give China a permanent naval presence in the western Indian ocean and a commanding position at the mouth of the Gulf. This dramatic expansion of the Chinese naval forces into what India sees as its home-ground is a matter of long-term security concern for India. ${ }^{24}$

The Japan-United States bonhomie is one of the oldest in Asia since the end of the Second World War. The post - Cold War Asian architecture of power has further consolidated U.S-Japan relationship. In recent years, China has been assertive and has negated international law recognising rights of neighbouring countries particularly in the South China Sea and the East China Sea and considers both waters as its own. Even after the 2016 international tribunal's decision against it on the South China Sea, it has openly defied the decision of the tribunal. Though China is a signatory of the 1982 UNCLOS, it is now violating international law since the decision doesn't serve it interests. Japan is not weak like other Chinese contested neighbours over waters and has challenged China. Interestingly, the United States has extended its support to Japan and reaffirmed that international law must be adhered to. It has further put strain in the bilateral relationship of Japan and China and in contrast has strengthened United States-Japan relationship. This situation is converging with the India-Japan bilateral relationship which has emerged as an important determining bilateral relationship in Asia. As a result, China feels cornered.

Domestically, Indian policymakers have long held contradictory views on China. Another big Asian country, India is frustrated that China's rise has captured much of the world's attention. Proud of its 'advanced political system', India feels superior to China. However, it faces a disappointing domestic situation which is unstable compared with China's. India likes to brag about its sustainable development, but worries that it is being left behind by China. China is seen in India as both a potential threat and a competitor to surpass. But India

\footnotetext{
${ }^{23}$ Mohan Malik, ed., Maritime Security in the Indo-Pacific: Perspectives from China, India, and the United States, Lanham: Rowman and Littlefield, 2014.

${ }^{24}$ Talmiz Ahmed, “Silk Road to Economic Heaven”, Herald, Karachi, 18 June 2016.
} 
can't actually compete with China in a number of areas, like international influence, overall national power and economic scale. India has apparently not realized this. Indian politicians seem to think their country would be doing China a huge favour simply by not joining the 'ring around China' established by the United States and Japan. India's growing power would have a significant impact on the balance in this equation, which has led India to think that fear and gratitude for its restraint will cause China to defer its attitude towards common territorial disputes. But this is wistful thinking, as China won't make any compromises in its border dispute with India. And while China wishes to coexist peacefully with India, this desire isn't born out of fear." 25

Geopolitical tensions between the United States and China are now increasing. ${ }^{26}$ As its power continues to grow, China will be more likely to challenge the United States' supremacy in East Asia and the Western Pacific. ${ }^{27}$ China rise has generated alarm bells and uncertainty in its regional neighbours, many of whom have territorial, maritime and other divergences with Beijing. The United States has vowed to contain China within Asia. Since China has historical baggage with many Asian countries, these countries are willing to contain China due to their own national interests. Japan, Vietnam, the Philippines, Malaysia, Indonesia, Singapore and India are important players in this equation. China's concerns about expanding Indo-US defence cooperation acquired an extra edge when it saw Tokyo join Washington in the security outreach to New Delhi. Japan has been the last among the great powers to sense India's rising power potential. During the final years of the premiership of Junichiro Koizumi and the brief tenure of Shinzo Abe, Japan has moved rapidly to define a new approach to India. ${ }^{28}$ Unlike much of East Asia, India carries no baggage about Japan's history or a grudge against its nationalism. The implementation of the Indo-US nuclear agreement and developments after PM Modi's November 2016 Tokyo visit on sensitive exports to India, could open the doors for a very rewarding high technology partnership between Tokyo and New Delhi. India and Japan have also agreed to expand their current defence cooperation which is focused on securing the sea-lanes in the Indian Ocean, which is immensely vital for Japanese access to energy and raw materials. ${ }^{29}$ Since the United States still remains the biggest balancer of Asia therefore deepening of United States-India relationship has pushed for a better Japan-India relationship. Indian policymakers are aware of Chinese reservations of India's admission to numerous East Asian platforms. India was admitted to the platforms despite Chinese protest and this has emboldened Japan's position, which is beneficial to India's strategic interests in Asia.

\section{Role of Russia}

Russia still possesses an important position within the prevailing security architecture of Asia. During President Obama's regime, U.S-Russia were strained. In November 2016, Donald Trump was elected as the new President of the United States. By the end of 2016, Trump had already antagonized China while taking to Taiwanese President Tsai Ing Wen which openly undermined China's core interests. In the last week of December 2016, the Obama administration expelled 35 Russian diplomats on gamut of charges but interestingly Russian

\footnotetext{
25 “India's unwise military moves", Global Times, 11 June 2009, available at http://opinion. globaltimes.cn/editorpicks/2009-06/436167.html.

${ }^{26}$ Aaron L. Friedberg, A Contest for Supermacy; China, America and Strguggle for Mastery in Asia, Norton, New York, 2011.

${ }^{27}$ Joseph S. Nye, "Is the American Century Over", Polity Press, Cambridge, 2015.

${ }^{28}$ James Lamont, "United States agrees weapons sales to India," Financial Times, 20 July 2009, available at http://www.ft.com/cms/s/0/663e6e04-7507-11de-9ed5-00144feabdc0.html.

${ }^{29}$ Gurpreet S. Khurana, "Security of Sea Lines: Prospects for India-Japan Cooperation," Strategic Analysis, Vol.31, No.1, January 2007.
} 
president Putin didn't reciprocate. Instead, he expected Trump will bring back normalcy in U.S-Russia relations. Although, Russia and China have emerged closer in recent years despite their serious regional divergences concerning Central Asia and the Russian Far east, both are adversaries to the United States. But recent trends indicate that Russia and United States may reduce gamut of conflicted issues under the Trump administration.

China is getting increasingly worried about the possibility of a thaw in the United States-Russia relations. Any improvement in their ties would seriously hurt Beijing's foreign policy goals, including its ability to deal with Japan and India. Stephen Blank, Senior Fellow for Russia at the Carnegie Insititute told the Times of India, that 'there is a lot of anxiety in Beijing that the Russians, who've all along taken an anti US stance, may start to think differently. If the US and Russia become closer, it implies China-Russia relationship would be effected." China is more since the newly appointed US Secretary of State, Rex Tillerson is an old friend of Putin's. In addition, the Chinese were alarmed when Putin flew to meet Shinzo Abe in 2017. This was the first time a Russian President visited Japan for bilateral talks in 11 years. The two inked deals worth $\$ 300$ billion even though there was no solution found to their border issues. It is possible that Japan is more than capable of offering sufficient investments to Russia in order to reduce its reliance on China.

\section{Impact on South Asia}

South Asia's geopolitical significance has increased many folds since the end of the Cold War. IIndia possesses $75 \%$ of South Asia by all counts. In the changing security architecture, Asia has become global battleground. Power equations in Asia are also changing rapidly. During the Cold War, Pakistan-U.S relations was strong but due to the situation in Afghanistan now, relations have soured somewhat. Japan-India relations have also increased many folds in the post Pokhran scenario. In contrast, China's relations with the United States and Japan have reduced and is bound to fall further due to the prevailing architecture of global and Asian powers. The arrival of President Trump in the White House has further complicated China's position as the US administration has no clear Asia policy.

China understands that deepening Indo-Japan relations have American blessings. Therefore China has enhanced its relations with Pakistan in recent years. It has given 'all weather relations' status to Pakistan despite the fact that Pakistan is exporting terror into the Chinese western turbulent province of Xingjiang. As mentioned previously the "One Belt One Road' which promotes the China-Pakistan Economic Corridor (CEPC) will eventually connect the Western Chinese city of Kashgar to the Pakistani western city of Gwador, which is strategically located at the mouth of the Persian Gulf and the Iranian border. Understanding that India is increasing its global profile, China is attempting to broaden India's containment within South Asia. China has already established a foothold in Nepal and Sri-Lanka and will try to replicate its imprint in the remaining countries of South Asia. China's President Xi Jinping visited Dhaka in October 2016 and pledged huge investments there. China is aware that its overture to Dhaka is being done against the backdrop of structural efforts by the Modi government to strengthen ties with Bangladesh.

The end of the Cold War coincided with the launching of India's 'Look East' policy. New Delhi gave unprecedented importance to the Asian balance of power within the contours of its foreign policy. The policy emphasized the core of post-Cold War Indian foreign policy. It was articulated by Prime Minister Atal Bihari Vajpayee during his 2002 visit to Singapore. He indicated that India's 'Look East' policy was not limited to Southeast Asia. Vajpayee declared that geography and politics made India an important part of the Asia-Pacific and that 
"it does not require formal membership of any regional organization for its recognition or sustenance". 30

India and Japan have been part of many bilateral and multilateral military exercises with other like-minded countries since last decade. Defence cooperation and non-security cooperation like disaster management are also being developed. Both countries have maintained a summit-level interaction for many years and trade is also gradually catching up. Since Indo-Japan relations has bipartisan support, it makes this bilateral bonhomie sustainable. Vajpayee provided a strong fundamental for relations, maintained its momentum and the Modi government propelled it further under the aegis of 'Act East' policy. The China-Japan rivalry has further consolidated india's relationship with Tokyo. In the second half of 2012, China claimed over the East China Sea Islands, which has been under Japanese control for many decades. China is willing to wield its economic and strategic aura to dominate its neighbours, which has been bitterly resisted by Japan. China's behaviour is akin to John Mershimer's concept of 'Offensive Realism.' It explains China's aggressive behaviour in an anarchic nature of the international system. As explained earlier, China has refused to obey international law in maritime disputes. Hence, in June 2016, the American Defence Secretary, Ashton Carter warned China over construction of disputed islands within SCS. ${ }^{31}$ Japan is worried that China may indulge in similar activities in the East China Sea and as such has sought to contain Beijing's influence by cooperating with India. For instance, when Prime Minister Narendra Modi hosted the Japanese Prime Minister Mr. Shinzo Abe for the 10th annual summit from 1113 December $2015,{ }^{32}$ the two leaders signed the 'Joint Statement on India and Japan Vision 2025: Special Strategic and Global Partnership Working Together for Peace and Prosperity of the Indo-Pacific Region and the World' and 'Fact Sheet: India and Japan, Working Together for Peace and Prosperity.' The visit built upon the substantive outcomes realized previously by moving forward towards an action-oriented partnership. Later, the negotiations on the agreement on civil nuclear energy cooperation was announced, which was signed following the completion of necessary internal procedures. The two sides further strengthened their economic partnership, with the expectation that Japanese ODA yen loan to India for the FY 2015 would reach a historic high of 400 billion yen, to projects ranging from urban metro rails, dedicated freight corridor and improving road networks, to industrial townships. In the defence sector, equipment and technology cooperation with joint research on potential avenues for coproduction and co-development as well as defence related agreements were signed, making way for a robust defence cooperation.

Socially, in order to promote people to people exchanges, India announced Visa on Arrival facility for Japanese visitors from March 2016 and the Japanese Prime Minister expressed that as many as 10,000 Indian youth would be eligible to visit Japan under a framework of student exchanges, IT training and other short-term exchanges over the next five years. The shared vision for peace and stability is exemplified in the strong condemnation of terrorism as well as the recognition of the Indo-Pacific as a region indispensable to each other's national security. All in all, Japanese support for India's membership to APEC, NSG and international export control regimes indicates Japan's deep commitment to cooperate with India on regional and multi-lateral issues.

\footnotetext{
${ }^{30}$ Atal Bihari Vajpayee, "India's Perspectives on ASEAN and the Asia-Pacific Region," 21 st Singapore Lecture, Institute of Southeast Asian Studies, 9 April 2002, available at http://www.iseas.edu.sg/ vajpayee.pdf.

31 "Beijing threatens to reject tribunal's decision on SCS," Times of India, New Delhi, 5 June 2016.

${ }^{32}$ Ministry of External Affairs, “Annual Report 2015-16,” Government of India, New Delhi, p 76.
} 


\section{Concluding Remarks}

Ever since the Modi Government came to power, India has taken a firm and sustainable stand that international law must be adhered to by all disputants of the South \& East China Seas. India has not only supported Japan and ASEAN countries in these disputes but has called upon the international community to ensure the compliance of the norm of international law of navigation and other relevant laws. When China adopted the globalization process in 1978, almost 13 years before India, Japanese companies began investing in China on a massive scale. The conflict over Islands between Japan and China in 2012 witnessed jingoistic protest in China. This situation compelled Japan to rethink over the relocation of its investments to India. Therefore, Japan increased the pace of investments in India and now is bound to further accelerate. In September 2017, Japanese PM Shinzo Abe visited India and many agreements were inked to propel this speed. Needless to say, that it will be positive for the growth of the Indian economy in a sustainable manner.

Prime Minister Modi converted 'Look East' policy into the 'Act East' policy and the deepening Indo-Japan relations is bound to be the fulcrum for the success of this policy due to the prevailing power architecture in Asia-Pacific. China's offensive realism has earned intense animosity against it within the region. Many countries support India as the counter weight to China. In the context of Japan-India relations, it has enhanced India's profile in the AsiaPacific. The Modi-led government has continuously raised the issue of South and East China Sea maritime disputes in international forums, which was not the case during previous Indian governments. The recent electoral victory of Japanese PM Shinzo Abe has further strengthened this increasing bonhomie since Abe has been the architect of Japan's India policy in the aftermath of the post -Cold War.

Deepening Indo-Japan relationship has huge imprints on South Asian security architecture. The Chinese are bound to accelerate their pace of containment of India within the region. Besides, the 'One belt One Road' initiative, the Chinese have given unprecedented importance to Pakistan in the last two decades, probably due to an increasing India's global profile. Since the end of the Cold War, each visiting Chinese leader has visited Islamabad after New Delhi. India continues to witness China-Pakistan nexus in many issues. Since China is determined to contain India within the ambit of South Asia, Pakistan's importance will be long term strategy for China. Growing Indo-US has further alarmed China and propelled Pakistan to come closer to contain the Indian imprint in South Asia. For New Delhi, India, Japan and United States have sustained their joint naval exercises (Malabar) for more than a decade. For the end, maritime security is the ultimate goal of these joint exercises in the Indian Ocean.

Given the Kautilyan notion that there are no permanent friends or foes in foreign policy and only convergences of interests, Indo-Japan relations are bound to reach newer heights in the foreseeable future. Deepening of bilateral relationship is mutually beneficial for both countries and in addition, it will strengthen justice based order in Asia in particular and at the global level in general. Since both countries are important stakeholders of Asian balance of power, their increasing bonhomie is all set to keep multi-polarity going within the evolving Asian security architecture.

\section{References}

"Beijing threatens to reject tribunal's decision on SCS," Times of India, New Delhi, 5 June 2016.

"India's unwise military moves", Global Times, 11 June 2009, available at http://opinion. globaltimes.cn/editor-picks/2009-06/436167.html.

"Japan Recalls China envoy over territory dispute", The Hindu, New Delhi, July 16, 2012. 
"Shinzo Abe, "Confluence of the Two Seas," (speech, Parliament of the Republic of India, 22 August 2007).

"The Latest Special Relationship in Asia," Financial Times, 3 September 2014, available at http://www.ft.com/intl/cms/s/0/d7558ebc-337d-11e4-

85f100144feabdc0.html?siteedition=intl\#axzz3CK4OHP4Y.

+ Sinha+at+Harvard+University.

Ahmed, T., "Silk Road to Economic Heaven", Herald, Karachi, 18 June 2016.

Dasgupta, S., "China sees growing India-Japan ties as move to counter it," The Times of India, New Delhi, September 20, 2012.

, "MEA fumes as sports min team ignores China sunb," The Times of India, New

Delhi, July 15, 2012.

Friedberg, A.L., A "Contest for Supermacy: China, America and Struggle for Mastery in Asia," Norton, New York, 2011.

Government of India, Ministry of External Affairs, "Tokyo Declaration for India-Japan Special Strategic and Global Partnership," 1 September 2014, available at http://www.mea.gov.in/bilateraldocuments.htm?dtl/23965/Tokyo+Declaration+for+India++J apan + Special + Strate gic + and + Global + Partnership.

Khurana, G.S., "Security of Sea Lines: Prospects for India-Japan Cooperation," Strategic Analysis, Vol.31, No.1, January 2007.

Lamont, J., "United States agrees weapons sales to India," Financial Times, 20 July 2009, available at http://www.ft.com/cms/s/0/663e6e04-7507-11de-9ed5-00144feabdc0.html.

Malik, M. ed., Maritime Security in the Indo-Pacific: Perspectives from China, India, and the United States, Lanham: Rowman and Littlefield, 2014.

Medcalf, R., Raja Mohan, C., "Responding to Rivalry: Australia, India and Middle-Power Coalitions,” Lowy Institute, (Sydney: Lowy Institute for International Policy, 2014).

Ministry of External Affairs, “Annual Report 2015-16," Government of India, New Delhi.

Naidu, G.V.C., "India and East Asia: The Look East Policy," Perceptions, Vol. 18, No.1, 2013, p 73.

Nye, J.S., "Is the American Century Over", Polity Press, Cambridge, 2015.

Rajendram, D., "India-Japan Ties in the Face of a Rising China," China India Brief, No.20, Lee Kuan Yew School of Public Policy, 28 January 2014, available at http://lkyspp.nus.edu.sg/cag/publication/china-india-brief/china-india-brief-.20

Scott, D., "India's Role in the South China Sea: Geopolitics and Geo-economics in Play," India Review, Vol. 12, no.2, 2013, p 55.

Sen, S.R., "For First Time Since World War 2, Japan will Sell Military Equipment. To India," NDTV, 2 September 2014, available at http://www.ndtv.com/article/india/for-first-time-sinceworld-war-2-japan-will-sellmilitary- equipment-to-india-585231.

Sinha, Y., "Speech by External Affairs Minister Shri Yashwant Sinha at Harvard University," (speech, Harvard University, Cambridge, 29 September 2003) available at http://mea.gov.in/Speeches-

Statements.htm?dtl/4744/Speech+by+External+Affairs+Minister+Shri+Yashwant

Vajpayee, A.B., "India's Perspectives on ASEAN and the Asia-Pacific Region," 21st Singapore Lecture, Institute of Southeast Asian Studies, 9 April 2002, available at http://www.iseas.edu.sg/ vajpayee.pdf. 